\title{
The effect of Coriandrum sativum seed extract on the learning of newborn mice by electric shock: interaction with caffeine and diazepam
}

This article was published in the following Dove Press journal:

Psychology Research and Behavior Management

20 January $201 \mathrm{I}$

Number of times this article has been viewed

\author{
Seyed Sadegh Zargar-Nattaj' \\ Pooya Tayyebi' \\ Vahid Zangoori ${ }^{1}$ \\ Yasaman Moghadamnia ${ }^{4}$ \\ Hasan Roodgari ${ }^{2}$ \\ Seyed Gholamali Jorsaraei ${ }^{3}$ \\ Ali Akbar Moghadamnia' \\ 'Department of Pharmacology, \\ ${ }^{2}$ Department of Medical Genetics, \\ ${ }^{3}$ Department of Anatomical Sciences \\ and Embryology, Babol University \\ of Medical Sciences, Babol, Iran; \\ ${ }^{4}$ Department of Physics, Alzzahra \\ University, Tehran, Iran
}

\begin{abstract}
Coriander has been recommended for the relief of pain, anxiety, flatulence, and loss of appetite. In traditional medicine, it is believed that coriander can induce some degree of amnesia in a child when his/her mother uses coriander during the pregnancy. We evaluated the effect of Coriandrum sativum seed extract on learning in second-generation mice. Ethanolic extract $(2 \%)$ of coriander (100 mg/kg intraperitoneal) was dissolved in sunflower oil (oil) as a vehicle and injected into the control group mother mice during breastfeeding for 25 days at 5-day intervals. After feeding the newborn mice, their learning was evaluated using a step-through passive avoidance task with $0.4 \mathrm{~mA}$ electric shock for 2 or 4 seconds. While coriander extract showed a negative effect in the short term (1 hour) after the training session, it potentiated the mice's learning in later assessments ( 24 hours post-training $[P=0.022]$ and 1 week post-training $[P=0.002]$ by a 4 -second shock). Low-dose caffeine $(25 \mathrm{mg} / \mathrm{kg}$ ip after training) improved the learning after 1 hour $(P=0.024)$; while diazepam $(1 \mathrm{mg} / \mathrm{kg}$ ip) suppressed learning at all time points after the 4-second shock training ( 1 hour, $P=0.022 ; 24$ hours, $P=0.002$; and 1 week, $P=0.008$ ). No modification in the pain threshold was elicited by electric stimuli both in coriander and control groups. In conclusion, coriander does not improve learning within a short period of time after training; however, learning after coriander administration can be improved in the long term.
\end{abstract}

Keywords: Coriandrum sativum, caffeine, diazepam, learning, memory, step through passive avoidance task

\section{Introduction}

Learning is an essential task and one of the most complex functions of the human brain. Despite studies conducted on learning and memory procedures, the exact mechanism of learning and memory remains unknown. It has been suggested that some neurotransmitters, such as epinephrine, serotonin, and dopamine, play a role in memory formation. ${ }^{1}$ Within the last decade, many investigations have focused on the effects of drugs, including herbal treatments, on the learning process. ${ }^{2-4}$ Coriandrum sativum or coriander (Apiaceae, and called Geshniz in Persian), a herb that is often used as a side dish in Iranian cooking, is a soft, hairless plant growing up to $50 \mathrm{~cm}$ in height and is native to Southwestern Asia and North Africa. All parts of the plant are edible, but the fresh leaves and the dried seeds are the most eaten parts of the plant. ${ }^{5}$ In traditional medicine, coriander is recommended for the relief of pain, anxiety, flatulence, loss of appetite, and convulsions. It is also known to enhance mental functioning. ${ }^{6}$ To date, many pharmacological effects have been reported for coriander, but few studies have focused on its effects on learning and memory. Based on previous studies, there is some controversy concerning our understanding of coriander's effects.
Correspondence: Ali Akbar Moghadamnia Department of Pharmacology, Babol University of Medical Sciences, 47|764|367, Babol, Iran Emailmoghadamnia@yahoo.com 
Although one study showed that coriander seeds covered in a little sugar could improve brain physiological activities such as memory, ${ }^{7}$ another study suggested coriander had a negative effect on learning and memory. ${ }^{8}$ However, there is an absence of reliable data in the literature concerning the effect of coriander on learning in the second generation of mice that receive coriander extract during their infant life or later through breastfeeding. The aim of the present study was to investigate the effect of coriander seed extract on learning in the second generation of mice that received the extract during infancy or breastfeeding.

\section{Materials and methods}

This animal study was approved by the local research ethics committee at Babol University of Medical Sciences.

\section{Animals}

Swiss albino mice weighing 20-30 g were purchased from the Pasteur Institute in Tehran, Iran. Each female and male mouse was coupled in separate cages for breeding at a room temperature of $22 \pm 1^{\circ} \mathrm{C}$ within a $12 \mathrm{~h}$ light/dark cycle (6:00 am to $6: 00 \mathrm{pm})$. The pregnant mice were then randomly divided into two groups - the case and control groups - and were kept in separated cages until delivery. The mother and the newborn mice were kept in the cage until the infant mice weighed up to 20-30 g. Then male and female mice were separated and were kept in separate cages until the test day. Treatment was commenced from the first day after delivery, and all injections were given to mothers. Case mothers were given coriander extract (100 $\mathrm{mg} / \mathrm{kg}$, intraperitoneal) from the first day to the $25 \mathrm{th}$ day (5-day intervals) after delivery, while the controls were given sunflower oil as control. In the next phase of the experiment, caffeine and/or diazepam were immediately given to the second-generation mice after a training session. All experiments of passive avoidance were done on the second-generation mice in a quiet room in the morning to minimize levels of noise and stress that could disturb the learning process. The investigator in all steps of the experiment was blinded.

\section{Preparation of coriander extract}

Coriandrum sativum seeds were purchased from a registered herbal medicine shop (Taheri Herbal Shop, Babol, Iran) and identified and authenticated by a specialist in pharmacognosy. A voucher specimen was deposited in the Department of Pharmacology, Babol University of Medical Sciences (number: CS_00237).
Dried seeds of coriander were ground to a fine powder. Ten grams of this powder was diluted using $50 \mathrm{~mL}$ of ethanol $80 \%$. This suspension was filtered by filter paper after 72 hours, and the extract was transferred to an open plate and kept for 14 days to achieve a concentrated form of the extract. ${ }^{9}$ The extract was dispersed in the sunflower oil before use.

\section{Drugs}

Diazepam hydrochloride (Daru Pakhsh, Tehran, Iran) at a dosage of 1 and $5 \mathrm{mg} / \mathrm{kg}$, and caffeine (powder; Sigma Co, Tehran, Iran) at dosages of 25 and $50 \mathrm{mg} / \mathrm{kg}$ were administered.

\section{Step through passive avoidance task}

The apparatus usin mice memory in Tsuji et al's work was based on Muromachi Kikai's study, ${ }^{10}$ with few modifications. It had two chambers, a bright $(10 \times 12 \times 15 \mathrm{~cm})$ and dark compartment $(14 \times 18 \times 15 \mathrm{~cm})$. A wooden, narrow wall with a guillotine door separated the chambers. The bright chambers were colored white. The test was carried out over three days. On the first day, or the training session, mice were individually placed in the bright compartment and were allowed to have free movement for 30 seconds. Afterwards, the guillotine door was raised to allow them to enter the dark compartment. The floor of the chamber was equipped with a wire network of wires to supply an electrical shock $(0.4 \mathrm{~mA}$, $60 \mathrm{v}$ ) to the mice entering the dark chamber. The electrical shock was delivered for 2 and/or 4 seconds; mice were then removed from the cages. In the test sessions, their learning level was assessed at 1 hour, 24 hours, and 1 week after the training session, using a step through passive avoidance task without shock. For this test, mice were placed in the bright compartment and were allowed to explore for 30 seconds. Then, the door was raised, and the latency time to enter the dark compartment was recorded for up to 300 seconds. This period of time was considered to be an assessment of the level of learning.

\section{Pain threshold}

The reaction of mice to electrical shock in the dark chamber of the passive avoidance device was evaluated as pain threshold. Mice were allowed $10 \mathrm{~min}$ to familiarize themselves with the surroundings of the device before they received six different intensities of electrical shock $(0.1,0.2,0.3$, $0.4,0.5$, and 0.6 mA). Shock duration was 2 seconds and they were given at 20 second intervals. Coriander $(100 \mathrm{mg} /$ $\mathrm{kg})$ or oil $(1 \mathrm{~mL} / \mathrm{kg})$ was pretreated 30 minutes before the delivery of electrical foot shocks. Jumping and flinching 
(forepaws off the grid floor) were considered as threshold of pain sensation. ${ }^{10}$

\section{Statistical analysis}

The data are presented as means $\pm \mathrm{SD}$, and the MannWhitney $U$ test was used to compare the medians of the two different groups for each time session. The Kruskal-Wallis $H$ test and the Friedman test were used to compare data between more than two different groups and for comparing data from the three sessions of training assessment within each group test, respectively. The surveillance of the main event (avoidance of entering in the dark chamber after training) was analyzed using the Kaplan-Meier test. Differences between groups were considered statistically significant at $P$-value under 0.05 .

\section{Results}

\section{Comparison of passive avoidance performance between mice receiving control and coriander}

The mean latency times to enter the dark compartment in the coriander group was decreased 1 hour after the training session, but was increased at 24 hours and 1 week after training at various shock levels when compared to the group receiving control (oil) (Tables 1 and 2). Surveillance analysis showed a significant difference between data from the two groups at 24 hours $(P=0.003$; Figure 1$)$. The control mice entered the shock compartment more quickly than the coriander mice at 24 hours and 1 week after taking coriander extract. These changes were statistically significant for the 4-second shock condition ( $P=0.002$; Table 2 ). However, there were no significant differences in the mean latency times after various shock levels between the coriander and control group at the 1 -hour test session $(P>0.05)$.

\section{Comparison of passive avoidance performance between mice receiving caffeine in oil pretreatment}

The mean latency times increased in the caffeine pretreatment ( $25 \mathrm{mg} / \mathrm{kg}$ ) group pretreated with oil after 1 hour, 24 hours, and 1 week after the 2 -second and 4-second shock conditions, in comparison with the saline group pretreated with oil; however, no significant changes were recorded $(P>0.05)$ (Tables 1 and 2). The mean latency time to enter the dark chamber increased in the caffeine $(50 \mathrm{mg} / \mathrm{kg})$ group pretreated with oil compared to the saline group that had received a similar pretreatment (Tables 1 and 2). This latency time was greater in the low-dose caffeine group than in the high-dose group (Tables 1 and 2).

\section{Comparison of passive avoidance performance between mice receiving caffeine and those receiving coriander pretreatment}

Table 1 indicates the effects of coriander pretreatment and caffeine injection $(50 \mathrm{mg} / \mathrm{kg})$ immediately after training among mice. Differences in the mean latency time to enter the dark chambers in the group receiving pretreatment with $25 \mathrm{mg} / \mathrm{kg}$ caffeine and those receiving saline and pretreatment of coriander were significant for the 2-second and 4-second shock conditions, especially 24 hours and 1 week after the training session $(P<0.01)$. In addition, the difference

Table I Mean $( \pm S D)$ time spent in the white chamber by mice of given 2-second of shock

\begin{tabular}{|c|c|c|c|c|}
\hline Group & I hour & 24 hours & I week & $P$ value \\
\hline Oil pretreatment + saline & $140.3 \pm 38.0$ & $32.3 \pm 10.7$ & $22.0 \pm 13.1$ & NS \\
\hline $\begin{array}{l}\text { Coriander pretreatment }+ \\
\text { saline }\end{array}$ & $50.3 \pm 22.9$ & $72.8 \pm 24.4$ & $48.1 \pm 15.9$ & NS \\
\hline$P$ value $^{\mathrm{a}}$ & NS & NS & NS & - \\
\hline $\begin{array}{l}\text { Oil pretreatment + caffeine } \\
25 \mathrm{mg} / \mathrm{kg}\end{array}$ & $170.7 \pm 137.5$ & $169.0 \pm 131.6$ & $104 \pm 115.7$ & NS \\
\hline $\begin{array}{l}\text { Coriander pretreatment + } \\
\text { caffeine } 25 \mathrm{mg} / \mathrm{kg}\end{array}$ & $236.7 \pm 102.7$ & $221.7 \pm 86.1$ & $276.0 \pm 49.6$ & 0.05 \\
\hline$P$ value & NS & NS & NS & - \\
\hline $\begin{array}{l}\text { Oil pretreatment + caffeine } \\
50 \mathrm{mg} / \mathrm{kg}\end{array}$ & $175.5 \pm 148.4$ & $50.8 \pm 54.0$ & $86.0 \pm 81.5$ & NS \\
\hline $\begin{array}{l}\text { Coriander pretreatment + } \\
\text { caffeine } 50 \mathrm{mg} / \mathrm{kg}\end{array}$ & $176.0 \pm 30.8$ & $82.2 \pm 12.3$ & $100.2 \pm 4.9$ & NS \\
\hline$P$ value & NS & 0.026 & 0.004 & - \\
\hline
\end{tabular}

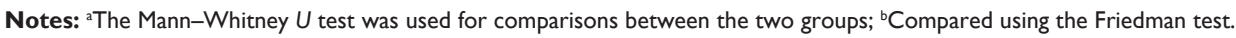
Abbreviation: NS, not significant. 
Table 2 Mean $( \pm S D)$ time spent in the white chamber by mice given 4-second of shock

\begin{tabular}{|c|c|c|c|c|}
\hline Group & I hour & 24 hours & I week & $P$ value $^{\mathrm{b}}$ \\
\hline Oil pretreatment + saline & $128.5 \pm 35.4$ & $26.3 \pm 11.4$ & $9.2 \pm 1.9$ & NS \\
\hline $\begin{array}{l}\text { Coriander pretreatment }+ \\
\text { saline }\end{array}$ & $102.1 \pm 29.0$ & $|5| .4 \pm 30.8$ & $169.6 \pm 47.9$ & NS \\
\hline$P$ value $^{\mathrm{a}}$ & NS & 0.022 & 0.002 & - \\
\hline $\begin{array}{l}\text { Oil pretreatment + caffeine } \\
25 \mathrm{mg} / \mathrm{kg}\end{array}$ & $129.8 \pm 144.2$ & $181.3 \pm 143.8$ & $95.7 \pm 115.4$ & NS \\
\hline $\begin{array}{l}\text { Coriander pretreatment + } \\
\text { caffeine } 25 \mathrm{mg} / \mathrm{kg}\end{array}$ & $227 \pm 80.1$ & $225.8 \pm 74.6$ & $276.3 \pm 58.0$ & 0.039 \\
\hline$P$ value & NS & NS & NS & - \\
\hline $\begin{array}{l}\text { Oil pretreatment + caffeine } \\
50 \mathrm{mg} / \mathrm{kg}\end{array}$ & $175.5 \pm 116.5$ & $177.8 \pm 119.0$ & $84.3 \pm 69.2$ & NS \\
\hline $\begin{array}{l}\text { Coriander pretreatment + } \\
\text { caffeine } 50 \mathrm{mg} / \mathrm{kg}\end{array}$ & $267.0 \pm 49.1$ & $229.5 \pm 19.6$ & $222.3 \pm 7.9$ & NS \\
\hline$P$ value & NS & NS & NS & - \\
\hline
\end{tabular}

Notes: ${ }^{a}$ Mann-Whitney $U$ test was used for comparisons between two groups; ' ${ }^{\circ}$ Compared via the Friedman test.

Abbreviation: NS, not significant.

between the group receiving $50 \mathrm{mg} / \mathrm{kg}$ of caffeine pretreated with coriander and the group receiving saline with the same pretreatment was considerable; however, changes were significant only 1 hour after the 2 -second and 4-second shock training session $(P=0.013$ and $P<0.005$, respectively). The Kruskal-Wallis $H$ test showed that there was a significant difference between data from the coriander pretreated saline group and the coriander pretreated caffeine (25 and $50 \mathrm{mg} / \mathrm{kg}$ ) groups only at 1 hour test session after training $(P=0.024$; Table 1). The Friedman test showed a significant difference within the group that received $25 \mathrm{mg}$ of caffeine (mice pretreated with coriander) at two different shock levels $(P<0.05$; Tables 1 and 2$)$. There was a significant discrepancy between the different doses of caffeine including

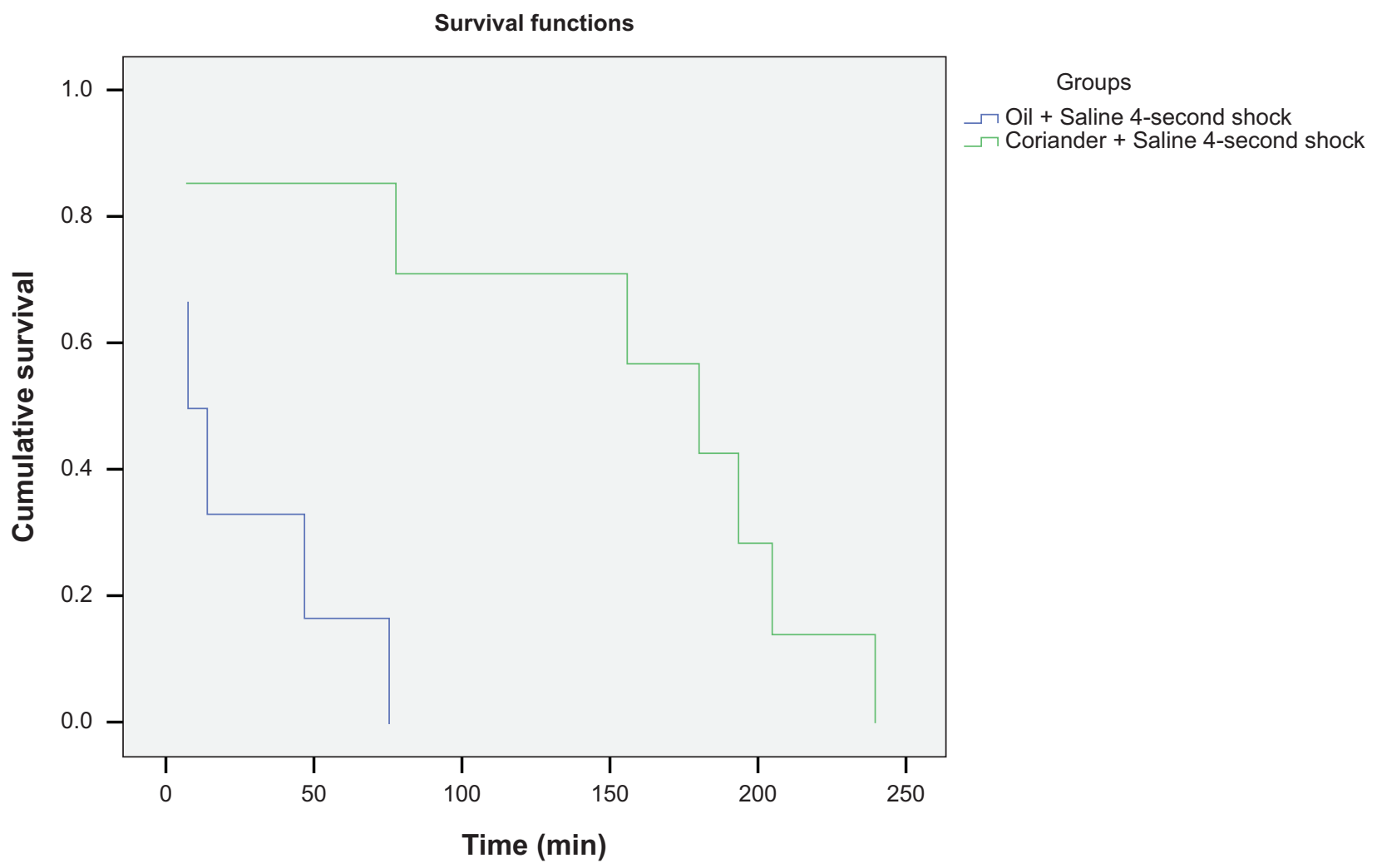

Figure I The Kaplan-Meier surveillance curve comparing the trend of events (entering or not entering the dark chamber) by mice $(\mathrm{n}=\mathrm{I} 2)$ at 24 hours after training with the 4-second shock. A comparison between mice that received saline in the oil and coriander pretreated groups (oil [blue line] and/or coriander [green line]). Significant differences were seen between groups $(P=0.003)$. 
$25 \mathrm{mg}$ and $50 \mathrm{mg}$, but only at 24 hours and 1 week after the 2 -second shock condition $(P<0.01)$. The data varied significantly among receivers of $25 \mathrm{mg} / \mathrm{kg}$ caffeine who were pretreated with coriander and pretreated with saline for the 2 -second and 4-second shock conditions, but only 1 week after training $(P<0.01)$.

\section{Comparison of passive avoidance performance of diazepam between mice pretreated with coriander and oil}

Diazepam ( $1 \mathrm{mg} / \mathrm{kg}$ and $5 \mathrm{mg} / \mathrm{kg}$ ) was immediately injected into coriander-pretreated mice after training. The results obtained from the group receiving diazepam $(1 \mathrm{mg} / \mathrm{kg})$ showed statistically significant differences at the 4-second shock condition when compared to saline groups at 1 hour after the test session ( $P=0.002$; Figure 2$)$. However, saline (pretreated with coriander) increased the time spent in the chamber, as compared to diazepam. The group analysis by the Friedman test showed statistically significant intra-group variations in mice receiving $1 \mathrm{mg} / \mathrm{kg}(P=0.042)$ and $5 \mathrm{mg} / \mathrm{kg}$ $(P=0.016)$ of diazepam.

\section{Effect of pretreatment with oil and coriander on the pain threshold}

Coriander and the oil's effect on pain threshold are shown in Figure 3. No significant differences were seen after pretreatment coriander (100 mg/kg, 30 minutes before shock) compared to oil on flinching response. Two mice in the oil group had shown moderate jumping after receiving shock $0.6 \mathrm{~mA}$.

\section{Discussion}

Based on the present investigation, we conclude that coriander in the short term after training has benzodiazepine-like effects on memory, with reversal of the effect in the long term after training ( 24 hours and 1 week). This may be due to the role of coriander metabolites in improving its action on long-term memory.

The aim of this study was to understand the effect of coriander extract on learning and memory processes among mice, while their mothers were receiving coriander extract during breastfeeding. Comparisons between the groups receiving coriander and control (oil) showed that the mean latency time to enter the dark chambers was significantly longer in the control group than the coriander group in the first hour, although the control group entered the dark chamber more quickly than the coriander group at 24 hours and 1 week after the training sessions.

To investigate whether the effects of drugs on passive avoidance performance are due to nonspecific mechanisms on pain threshold, it was investigated in an analgesia assessment using different electric shocks as nociceptive stimulus. None of the drugs at the equal doses have shown significant effects on nociception threshold for flinching and jumping. This finding showed that the effect of coriander is due to changes in the learning process not due to changes in the nociception threshold.

Hence, the first experiment demonstrated that coriander had a negative effect on memory and learning; however, this negative effect occurred only for a short period of time (for

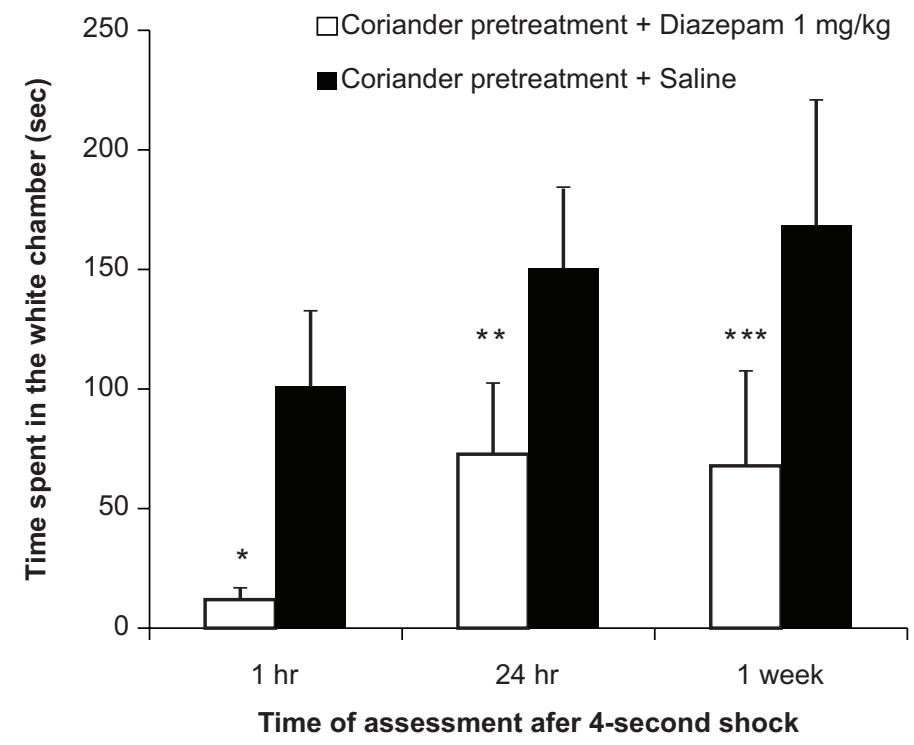

Figure 2 Mean ( \pm SEM) time (seconds) spent in the white chamber (avoidance behavior after the 4-second shock) of mice $(\mathrm{n}=12)$ pretreated with coriander receiving diazepam (blank bars, I mg/kg) or saline $(0.1 \mathrm{~mL} / \mathrm{kg}$, solid bars) at different time sessions.

Notes: $* P=0.022 ; * * P=0.002 ; * * * P=0.008$. 


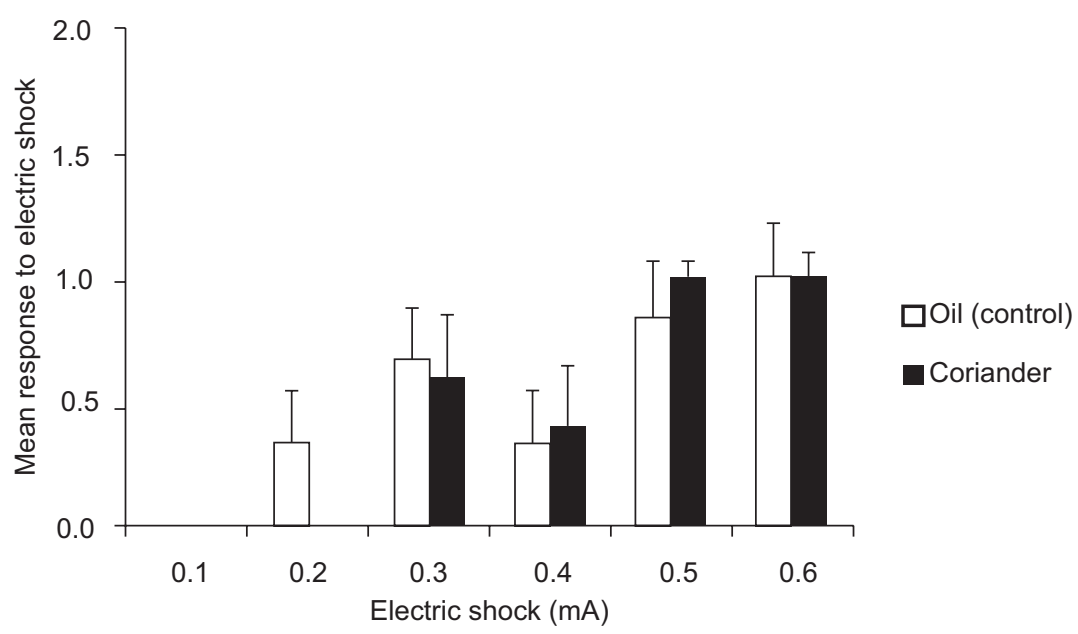

Figure 3 Effect of oil ( $1 \mathrm{~mL} / \mathrm{kg}$, ip, 30 minutes before shock) and coriander ( $100 \mathrm{mg} / \mathrm{kg}$, ip, 30 minutes before shock) pretreatment on pain threshold in mice. Each column represents the mean and SEM of flinching response in six mice.

the first hour). These results are in line with an investigation conducted by Moattar and Takhesh in 1999 that showed that the extract of Coriandrum sativum seed might have a negative effect on memory. ${ }^{8}$ However, the real mechanism of coriander's effect on memory is still unclear, as such an effect is thought to be due to the impact of coriander's metabolites on various parts of the brain that are important for memory and learning skills. For example, the metabolites may interact with the functioning of the hippocampus or with the synthesis of memory neurotransmitters, including serotonin and epinephrine. Although it is difficult to interpret the effect of coriander in this study, based on the previous studies, the interaction of coriander with caffeine or diazepam could be determined. However, the present study demonstrates that caffeine increased learning abilities, regardless of coriander administration. Of note, this effect increased by a great deal when we compared groups receiving $25 \mathrm{mg} / \mathrm{kg}$ of caffeine with those receiving $50 \mathrm{mg} / \mathrm{kg}$ of caffeine. However, the difference in latency times between the caffeine-treated and noncaffeine-treated coriander group was statistically significant. This was not true for the control group. Many studies have suggested that caffeine has a dual effect, that is to say, low-dose caffeine (25-50 mg/kg) improves memory quality, but fails to do so at higher doses (greater than $50 \mathrm{mg} / \mathrm{kg}$ ). ${ }^{11-13}$ Thus, the effect appears to be dose-dependent. Caffeine is a nonselective competitive $\mathrm{A}_{1}$ and $\mathrm{A}_{2 \mathrm{~A}}$ receptor antagonist, and both receptors have similar affinities for caffeine. ${ }^{14}$ All four subtypes of the adenosine $\left(A_{1}, A_{2 A}, A_{2 B}\right.$, and $\left.A_{3}\right)$ receptor are heterogeneously distributed through the brain tissue, especially in the cortex and hippocampus. ${ }^{15}$ Activation of these receptors directly or indirectly decreases the release of acetylcholine from hippocampal neurons. ${ }^{16}$ Acetylcholine is a neurotransmitter that affects the processes of memory and learning. ${ }^{17}$ Caffeine at lower doses $(25 \mathrm{mg} / \mathrm{kg})$ antagonizes A1 receptors and increases the release of acetylcholine, which improves memory. Some studies have suggested that the effect of caffeine on learning is not dose dependent. Increased doses of caffeine increase locomotor activity in mice, and such mice are also more likely to enter the dark compartment chaotically in passive avoidance models. This was not related to the suppressing effect of high dose caffeine. ${ }^{12}$ This effect is thought to be related to the action of caffeine on $A_{2 A}$ receptors, namely that it causes activation of the $\mathrm{A}_{2 \mathrm{~A}}$ receptor, which probably influences dopaminergic neurotransmission. ${ }^{18}$ It is well known that benzodiazepines have a negative effect on memory and have been used by anesthesiologists since in 1964. ${ }^{19}$ The suppressive effect of benzodiazepines on learning and memory, especially in the encoding stage, has been confirmed by investigations. ${ }^{20-22}$ In our study, mice in the group with coriander pretreatment that were given diazepam had the shortest average latency time; these changes were statistically significant. This observation clearly showed that diazepam has a negative effect on memory. On the other hand, diazepam decreased avoidance performance, as assessed by time in the dark compartment, but coriander can improve its negative effect on performance. In addition to the $\mathrm{A}_{1}$ and $\mathrm{A}_{2 \mathrm{~A}}$ receptors, it was reported that caffeine can antagonize benzodiazepine receptors in the brain. ${ }^{23}$ We also concluded that caffeine can reverse the negative effect of benzodiazepines and the short-term effect of coriander on learning and memory via its antagonist effect on benzodiazepine receptors.

Based on our findings, we concluded that coriander has a negative short-term effect on memory and learning; however, in the long-term, it improves the performance of mice in 
the passive avoidance task. Caffeine has a dual effect that is dose-dependent. Caffeine at low doses increases learning performance in mice, while at high doses it suppresses learning. This study also confirmed the suppressive effects of benzodiazepines on learning.

\section{Acknowledgments}

The authors wish to thank Ms Zaker-Abbasi, Miss Hashemi, and Mr Alijani for their laboratory and technical support.

\section{Disclosure}

No conflicts of interest were declared in relation to this paper.

\section{References}

1. Myhrer T. Neurotransmitter systems involved in learning and memory in the rat: a meta-analysis based on studies of four behavioral tasks. Brain Res Brain Res Rev. 2003;41:268-287.

2. Ikarashi Y, Iizuka S, Imamura S, et al. Effects of yokukansan, a traditional Japanese medicine, on memory disturbance and behavioral and psychological symptoms of dementia in thiamine-deficient rats. Biol Pharm Bull. 2009;32:1701-1709.

3. Jin UH, Kim JH, Chang GT, Kim JK, Chung KH, Kim CH. Enhancement of learning and memory by a medicinal formulation, Saenhyetang, in mice. J Ethnopharmacol. 2007;109:271-280.

4. Yang MH, Yoon KD, Chin YW, et al. Neuroprotective effects of Dioscorea opposita on scopolamine-induced memory impairment in in vivo behavioral tests and in vitro assays. $J$ Ethnopharmacol. 2009;121: $130-134$.

5. Burdock GA, Carabin IG. Safety assessment of coriander (Coriandrum sativum L.) essential oil as a food ingredient. Food Chem Toxicol. 2009; 47:22-34.

6. Avecina A. Ghanoon in Medicine. Tehran, Iran: Soroush Co. 1991;2: 196-197.

7. Adams M, Gmunder F, Hamburger M. Plants traditionally used in age related brain disorders - a survey of ethnobotanical literature. J Ethnopharmacol. 2007;113:363-381.

8. Moattar F, Takhesh AA. The effect of coriander herb and seeds extract on learning and memory in rats. 14th Iranian congress of physiology and pharmacology. Conference Proc. 1999:530.

9. Harborne JB. Phytochemical Methods. London, UK: Chapman and Hall. 1973;1:128-129.
10. Tsuji M, Takeda H, Matsumiya T. Modulation of passive avoidance in mice by the 5-HT1A receptor agonist flesinoxan: comparison with the benzodiazepine receptor agonist diazepam. Neuropsychopharmacology. 2003;28:664-674.

11. Angelucci ME, Cesario C, Hiroi RH, Rosalen PL, da Cunha C. Effects of caffeine on learning and memory in rats tested in the Morris water maze. Braz J Med Biol Res. 2002;35:1201-1208.

12. Angelucci ME, Vital MA, Cesario C, Zadusky CR, Rosalen PL, da Cunha C. The effect of caffeine in animal models of learning and memory. Eur J Pharmacol. 1999;373:135-140.

13. Zarrindast MR, Moghadamnia AA. Adenosine receptor agents and conditioned place preference. Gen Pharmacol. 1997;29:285-289.

14. Karcz-Kubicha M, Antoniou K, Terasmaa A, et al. Involvement of adenosine $\mathrm{A} 1$ and $\mathrm{A} 2 \mathrm{~A}$ receptors in the motor effects of caffeine after its acute and chronic administration. Neuropsychopharmacology. 2003; 28:1281-1291.

15. Van Dort CJ, Baghdoyan HA, Lydic R. Adenosine A(1) and A(2A) receptors in mouse prefrontal cortex modulate acetylcholine release and behavioral arousal. J Neurosci. 2009;29:871-881.

16. Jin S, Johansson B, Fredholm BB. Effects of adenosine A1 and A2 receptor activation on electrically evoked dopamine and acetylcholine release from rat striatal slices. J Pharmacol Exp Ther. 1993;267: 801-808.

17. Gold PE. Acetylcholine modulation of neural systems involved in learning and memory. Neurobiol Learn Mem. 2003;80:194-210.

18. Fredholm BB. Adenosine actions and adenosine receptors after 1 week treatment with caffeine. Acta Physiol Scand. 1982;115:283-286.

19. Brandt AL, Oakes FD. Preanesthesia medication: double-blind study of a new drug, diazepam. Anesth Analg. 1965;44:125-129.

20. Izquierdo I, Pereira ME, da Cunha C, Wolfman C, Medina JH. Benzodiazepine receptor ligand influences on learning: an endogenous modulatory mechanism mediated by benzodiazepines possibly of alimentary origin. Mem Inst Oswaldo Cruz. 1991;86(Suppl 2): 169-171.

21. Buffett-Jerrott SE, Stewart SH. Cognitive and sedative effects of benzodiazepine use. Curr Pharm Des. 2002;8:45-58.

22. Nabeshima T, Tohyama K, Ichihara K, Kameyama T. Effects of benzodiazepines on passive avoidance response and latent learning in mice: relationship to benzodiazepine receptors and the cholinergic neuronal system. J Pharmacol Exp Ther. 1990;255:789-794.

23. Kaplan GB, Greenblatt DJ, Leduc BW, Thompson ML, Shader RI. Relationship of plasma and brain concentrations of caffeine and metabolites to benzodiazepine receptor binding and locomotor activity. J Pharmacol Exp Ther. 1989;248:1078-1083.
Psychology Research and Behavior Management

\section{Publish your work in this journal}

Psychology Research and Behavior Management is an international, peerreviewed, open access journal focusing on the science of psychology and its application in behavior management to develop improved outcomes in the clinical, educational, sports and business arenas. Specific topics covered include: Neuroscience, memory \& decision making; Behavior

\section{Dovepress}

modification \& management; Clinical applications; Business \& sports performance management; Social and developmental studies; Animal studies. The manuscript management system is completely online and includes a quick and fair peer-review system. Visit http://www.dovepress. com/testimonials.php to read real quotes from published authors. 